

\title{
JURNAL SAINS DAN TEKNOLOGI
}

JURNAL PENELITIAN DAN KARYA ILMIAH STMIK DHARMASRAYA

\section{Penerbit}

Lembaga Penelitian dan Pengabdian Kepada Masyarakat

Sekolah Tinggi Manajemen Informatika dan Komputer Dharmasraya

Pelindung

Epri Yuldi, S.Kom, M.Kom (Ketua STMIK Dharmasraya)

Penanggung Jawab

Gunawan Ali, S.Kom, M.Kom (Ketua LPPM STMIK Dharmasraya)

Pimpinan Redaksi

Wahyu Prima, S.Kom, M.Kom

Sekretaris

Firmansyah Putra, S.Kom

Bendahara

Wulan Andang Purnomo, S.Pd, M.Kom

Dewan Editor

Adi Fitra Andikos, S.Kom, M.Kom (STMIK Dharmasraya) Raimon

Efendi, SAB, M.Kom (STMIK Dharmasraya)

Fauzi Tri Yuniko, S.Kom, M.Kom (STMIK Dharmasraya)

Moh. Rosyid Mahmudi, M.Si (STKIP Dharmasraya)

Estuhono, M.Pd (STKIP Dharmasraya)

\author{
Alamat Redaksi \\ Kampus STMIK Dharmasraya \\ Jln. Lintas Sumatera KM 18 Koto Baru \\ Dharmasraya, Sumatera Barat \\ Email: $\underline{\text { stmikdmr@gmail.com }}$
}

Jurnal Sains dan Teknologi STMIK Dharmasraya merupakan Jurnal Penelitian dan Karya Ilmiah yang diterbitkan oleh LPPM STMIK Dharmasraya yang terbit dua kali setahun. Jurnal Sains dan Teknologi STMIK Dharmasraya menerima naskah ilmiah hasil penelitian, telaah, maupun review dalam bidang sains dan teknologi untuk dipublikasikan pada jurnal ini. Naskah yang diterima akan disunting dan dievaluasi. Penyuntingan dilakukan untuk keseragaman format tanpa mengubah maksud. 


\section{DAFTAR ISI}

PENDATAAN INDUSTRI KECIL DAN MENENGAH (IKM) DI KABUPATEN PESISIR SELATAN BERBASIS WEB OLEH

GUSRINO YANTO.

ALGORITMA C4.5 DALAM DATA MINING UNTUK MENENTUKAN KLASIFIKASI KELULUSAN CALON DOSEN

BARU OLEH ADI FITRA ANDIKOS.

VALIDITAS BAHAN AJAR MULTIMEDIA INTERAKTIF DALAM BENTUK COMPACT DIST MULTIMEDIA INTERACTIF (CMI) PADA MATA KULIAH IPA SEKOLAH DASAR OLEH ESTUHONO. 78

ANALISIS GELOMBANG ELEKTROMAGNETIK TRANSVERSE MAGNETIK (TM) PADA PANDU GELOMBANG KRISTAL FOTONIK 2D MODEL T MENGGUNAKAN METODE TENSOR

GREEN OLEH MOH ROSYID MAHMUDI. 83

PERANAN TEKNOLOGI INFORMASI DALAM PELAYANAN KEPERAWATAN DI RUMAH SAKIT OLEH CANDRA SYAH

PUTRA. 90

SISTEM PAKAR DIAGNOSA PENYAKIT MATA PADA MANUSIA MENGGUNAKAN METODE FORWARD CHAINING OLEH FAIZA

RINI . 95

SISTEM PAKAR BIMBINGAN KONSELING PADA SISWA MENGGUNAKAN METODE FORWARD CHAINING OLEH WULAN ANDANG PURNOMO. 103

ANALISIS PELAKSANAAN PROGRAM MENTORING BASIC KEISLAMAN MENGGUNAKAN GOAL BASED EVALUATION 
PERANAN TEKNOLOGI INFORMASI PADA BIDANG FARMASI OLEH ITA DWIAINI . 118 DESIGN SYSTEM ROBO SMOKE DETECTOR OLEH ABDUL JABBAR LUBIS 121

SISTEM PENGAMANAN FILE DATA MENGGUNAKAN METODE ATTRIBUT KEYING, COMPRESSION KEYING DAN ENKRIPSI

OLEH AHMAD ZAKIR 129

PENENTUAN RESIKO PENYAKIT GINJAL PADA SISTEM PENGAMBILAN KEPUTUSAN DENGAN PROBABILITAS BAYES

OLEH HAIDA DAFITRI 135

PENGEMBANGAN MODEL PROSES ASSESMENT MODEL (PAM) MENGGUNAKAN COBIT5 OLEH MARISCHA ELVENY

MODEL AVERAGE BASED FUZZY TIME SERIES OLEH UMMUL KHAIR

PENERAPAN METODE PROGRAM LINEAR PADA SISTEM PENDUKUNG KEPUTUSAN PENENTUAN BEASISWA OLEH GUNAWAN ALI

PENERAPAN METODE ANALYTICAL HIERARCHY. PROCESS (AHP) DALAM PEMILIHAN GURU BERPRESTASI PADA SDN 01 ABAI SIAT KECAMATAN KOTO BESAR KABUPATEN DHARMASRAYA OLEH WAHYU PRIMA DAN GUNAWAN ALI . 


\title{
ALGORITMA C4.5 DALAM DATA MINING UNTUK MENENTUKAN KLASIFIKASI KELULUSAN CALON DOSEN BARU
}

\author{
Adi Fitra Andikos \\ Program Studi Sistem Informasi, Fakultas Ilmu Komputer, Universitas Dharmas Indonesia \\ Jln. Lintas Sumatera Km.18 Koto Baru, Dharmasraya, Sumatera Barat \\ Email: Andicos_afa@yahoo.co.id
}

\begin{abstract}
Abstrak
Selama ini informasi yang diberikan dalam menentukan kelulusan calon dosen baru hanya bisa dilihat berdasarkan Nilai Tes Seleksi Penerimaan calon dosen/Nilai Tertulis, yang menunjukkan kualitas calon calon dosen secara umum tanpa mengetahui keahlian yang benar-benar dimiliki oleh calon Dosen tersebut. Salah satu bagian yang penting pada sebuah perguruan tinggi adalah memiliki dosen yang berkualitas. untuk menentukan kelulusan calon calon dosen menggunakan bahasa seharihari dan menerapkan Algoritma c4.5 dalam data mining yang pastinya nanti dalam pengambilan keputusan akan lebih mudah dipahami guna menjadikan sebagai pembelajaran untuk kedepannya dalam menghasilkan para calon dosen yang bermutu. Untuk memberikan informasi dalam menentukan kelulusan calon dosen baru di Universitas Dharmas Indonesia klasifikasi dan prediksi adalah dua bentuk analisis data yang bisa digunakan untuk mengekstrak model dari data yang berisi kelas-kelas atau untuk memprediksi trend data yang akan datang. Menerapkan Algoritma c4.5 dalam data mining diharapkan mampu memberikan informasi kepada pihak perguruan tinggi untuk memiliki dosen yang berkualitas dan berkopeten dibidang mereka masing-masing.
\end{abstract}

Kata Kunci: Data Minig, Klasifikasi, Algoritma C4.5, Pohon Keputusan, Dosen Baru.

\section{Pendahuluan}

Untuk menerapkan konsep data mining banyak cara yang dapat digunakan diantaranya adalah menggunakan konsep beberapa algoritma yang ada pada data mining. Algoritma C4.5 adalah salah satu algoritma yang digunakan untuk melakukan klasifikasi data dengan membentuk pohon keputusan (Kusrini dan Emha Taufiq Luthfi, 2009). Proses pada pohon keputusan adalah mengubah bentuk data (tabel) menjadi model pohon, mengubah model pohon menjadi rule, dan menyederhanakan rule (Basuki dan Syarif, 2003). Pemanfaatan atau penerapan data mining tersebut menjadi salah satu elemen yang terpenting untuk dicermati perkembangannya. Tujuan dari semua itu hanyalah untuk memudahkan pemakai dalam melaksanakan pekerjaan dan mengakomidasi setiap bentuk kebutuhannya.

Suatu kriteria yang diberikan dalam pengambilan keputusan adakalanya melibatkan penggunaan variabel tujuan. Dengan menggunakan algoritma C4.5 maka akan dilakukan pengambilan informasi yang hasil penelitiannya dapat dijadikan contoh dalam masalah pengambilan keputusan yang melibatkan data-data yang pasti. Salah satu organisasi yang memerlukan langkah-langkah pengolahan data adalah Universitas Dharmas Indonesia.

Data mining adalah serangkaian proses untuk menggali nilai tambah dari suatu kumpulan data berupa pengetahuan yang selama ini tidak diketahui secara manual. Kata mining berarti usaha untuk mendapatkan sedikit barang berharga dari sejumlah besar material dasara (Pramudiono, 2003). Data mining merupakan proses pencarian pola relasi-relasi yang tersembunyi dalam sejumlah data yang besar dengan tujuan untuk melakukan klasifikasi, estimasi, prediksi, association rule, clustering, deskripsi dan visualisasi (Han dan Kamber, 2001).

Secara garis besar data mining menjadi 2 kategori utama, yaitu (Tan et al, 2005):

1. Descriptive mining, yaitu proses untuk menemukan karakteristik penting dari data dalam suatu basis data. Teknik data mining yang termasuk dalam descriotive mining adalah clustering, association, dan sequential mining.

2. Predictive, yaitu proses untuk menemukan pola dari data dengan menggunakan beberapa variabel lain di masa depan. Salah satu teknik yang terdapat dalam predictive mining adalah klasifikasi.

Secara sederhana data mining bisa dikatakan sebagai proses menyaring atau "menambang" pengetahuan dari sejumlah data yang besar. Istilah lain untuk data mining adalah Knowledge Discovery in Database atau KDD. Tujuan dari adanya data mining adalah (Thomas, 2004):

1. Explanatory, yaitu untuk menjelaskan beberapa kegiatan observasi atau suatu kondisi.

2. Confirmatory, yaitu untuk mengkonfirmasikan suatu hipotesis yang telah ada.

3. Exploratory, yaitu untuk menganalisis data baru suatu relasi yang janggal. 
Secara umum, proses klasifikasi dapat dilakukan dalam dua tahap, yaitu proses belajar dari data pelatihan dan klasifikasi kasus baru. Pada proses belajar, algoritma klasifikasi mengolah data pelatihan untuk menghasilkan sebuah model. Setelah model diuji dan dapat diterima, pada tahap

klasifikasi, model tersebut digunakan untuk memprediksi kelas dari kasus baru untuk membantu proses pengambilan keputusan (Han, 2001; Quinlan, 1993).

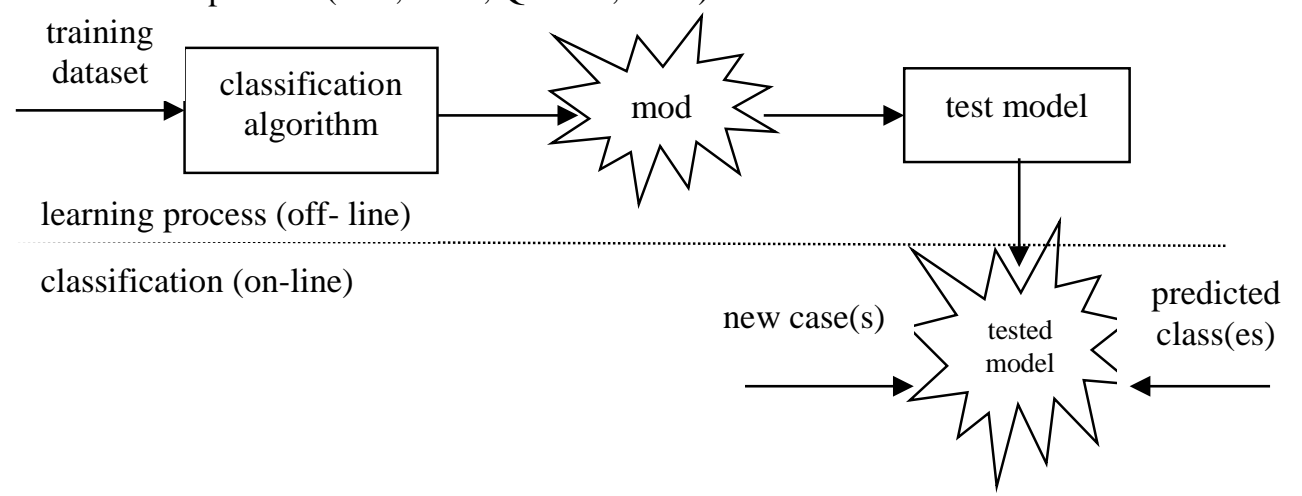

Gambar 1. Skema Klasifikasi Secara Umum

\section{Algoritma C 4.5}

Algoritma C4.5 adalah algoritma klasifikasi data dengan teknik pohon keputusan yang terkenal dan disukai karena memiliki kelebihan-kelebihan. Kelebihan ini misalnya : dapat mengolah data numerik (kontinyu) dan diskret, dapat menangani nilai atribut yang hilang, menghasilkan aturanaturan yang mudah diinterpretasikan dan tercepat di antara algoritma-algoritma yang menggunakan memori utama di komputer (Quinlan, 1993; Han et al., 2001; Berry et al., 1997; Ruggieri, 2001).

\section{Algoritma Konstruksi Pohon}

Algoritma dasar untuk induksi pohon keputusan pada C4.5 (dan turunannya) adalah algoritma greedy yang membangun pohon keputusan dari atas ke bawah (top-down) secara rekursif dengan cara divide dan conquer. Masukan dari algoritma ini adalah himpunan data yang berisi sampel-sampel data dan kandidat atribut yang harus ditelaah, terdiri dari minimal sebuah atribut prediktor dan sebuah atribut kelas. Atribut prediktor dapat bertipe diskret atau numerik, sedangkan atribut kelas harus bertipe diskret. Dalam terminologi basisdata, himpunan data ini berupa tabel, sedangkan sampel adalah record. Himpunan data ini dapat memiliki atribut (kolom tabel) bertipe diskret maupun kontinyu. Pada level teratas, pohon memiliki sebuah simpul yang merepresentasikan atribut prediktor yang digunakan untuk membuat cabang atau daun di level di bawahnya (atribut ini dinamakan atribut split). Jika atribut prediktor bertipe diskret (ad), cabang simpul dibuat untuk setiap nilai unik pada atribut diskret ini ( $v l$, $v 2, \ldots, v m)$. Sedangkan jika atribut prediktor bertipe kontinyu atau numerik (an), cabang simpul dibuat untuk dua buah nilai, yaitu an $\leq v t h$ dan an $>v t h$, dimana $v$ th adalah sebuah nilai ambang yang didapat dari nilai-nilai an.

\section{Komputasi Gain Ratio pada Konstruksi Pohon C4.5}

Pada konstruksi pohon C4.5, di setiap simpul pohon, atribut dengan nilai gain ratio yang tertinggi dipilih sebagai atribut test atau split untuk simpul. Rumus dari gain ratio adalah : gain ratio $(a)=\operatorname{gain}(a)$ / split info(a)

dimana gain(a) adalah information gain dari atribut $a$ untuk himpunan sampel $X$ dan split info(a) menyatakan entropi atau informasi potensial yang didapat pada pembagian $X$ menjadi $n$ sub himpunan berdasarkan telaahan pada atribut $a$. Sedangkan gain $(a)$ didefinisikan sebagai : gain $(\mathrm{a})=\operatorname{info}(X)-$ info $_{a}(X)$

Sedangkan rumus split info( $a)$ adalah

$$
\text { split info }(a)=-\sum_{i=1}^{n} \frac{\left|X_{i}\right|}{|X|} \times \log _{2}\left(\frac{\left|X_{i}\right|}{|X|}\right)
$$

dimana $X i$ menyatakan sub himpunan ke-i pada sampel $X$.

Alasan penggunaan gain ratio(a) pada C4.5 (bukan gain $(a)$ ) sebagai kriteria pada atribut yang memiliki banyak nilai unik. Pembagian gain(a) dengan split info(a) dimaksudkan untuk sampel $X 1 . . X n$, dimana $n$ adalah jumlah nilai unik pada atribut dan $X i$ adalah sub sampel yang memiliki nilai atribut $a$ $=i$. 
Untuk menghitung nilai info $a(X)$, jika $a$ adalah atribut diskret, maka sampel $X$ dibagi menjadi sub sampel $X 1 \ldots X n$, dimana $n$ adalah jumlah nilai unik pada atribut $a$ dan $X i$ adalah sub sampel yang memiliki nilai atribut $a=i$. Secara umum algoritma $C 4.5$ untuk membangun pohon keputusan adalah sebagai berikut :

1. Pilih atribut sebagai akar

2. Buat cabang untuk tiap-tiap nilai

3. Bagi kasus dalam cabang

4. Ulangi proses untuk setiap cabang sampai semua kasus pada cabang memiliki kelas yang sama

Untuk memilih atribut sebagai akar, didasarkan pada nilai gain tertinggi dari atribut-atribut yang ada. Untuk menghitung gain digunakan rumus seperti tertera dalam persamaan berikut :

Di mana :

$$
\operatorname{Gain}(S, A)=\operatorname{Enropy}(s)-\sum_{i=1}^{n} \frac{|S i|}{|S|} * \operatorname{Entropy}(S i)
$$

S : himpunan kasus

A : atribut $\mathrm{n}$ : jumlah partisi

atribut $\mathrm{A} \quad \mathrm{Si}$ : jumlah kasus pada

parti\$i ke-i

S | : jumlah kasus dalam $S$

Sementara itu, perhitungan nilai entropi dapat dilihat pada persamaan berikut :

$$
\text { Entropy }(S)=\sum_{i=1}^{n} \frac{|S i|}{|S|}-p i * \log _{2} p i
$$

Di mana :

S : himpunan kasus

A : fitur $\mathrm{n}$ :

jumlah partisi $\mathrm{S}$

pi : proporsi dari Si terhadap $\mathrm{S}$

\section{Metodologi Penelitian}

Pembahasan dan penyelesaian penelitian ini dilakukan dengan mengikuti kerangka kerja yang terdiri dari 7 tahapan.

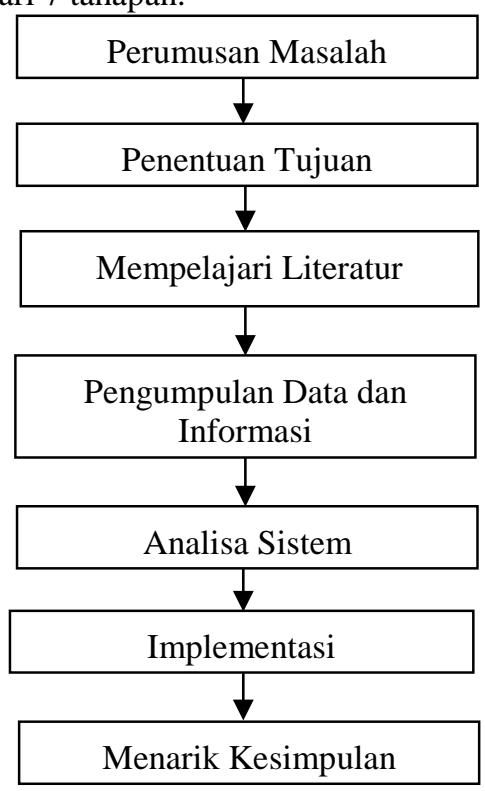

Gambar 2. Kerangka Penelitian

\section{Hasil Dan Pembahasan}

Proses klasifikasi kelulusan calon Dosen baru diproses dengan membuat pohon keputusan untuk menghasilkan suatu output. Di mana data tersebut mempunyai beberapa kriteria yang merupakan syarat dalam pengklasifikasian kelulusan calon Dosen baru. Data tersebut merupakan data input klasifikasi kelulusan calon Dosen baru. Data yang telah didapat dianalisa seehingga dikelompokkan menjadi 
beberapa kelompok data yang dapat diproses dengan merancang pohon keputusan. Proses pengambilan keputusan dalam klasifikasi calon Dosen baru dikelompokkan menjadi beberapa kriteria yaitu :

1. Kriteria Nilai Ujian Tertulis

2. Kriteria Nilai Wawancara

3. Kriteria Nilai Ujian Praktek

4. Kriteria Nilai Rata-rata IPK

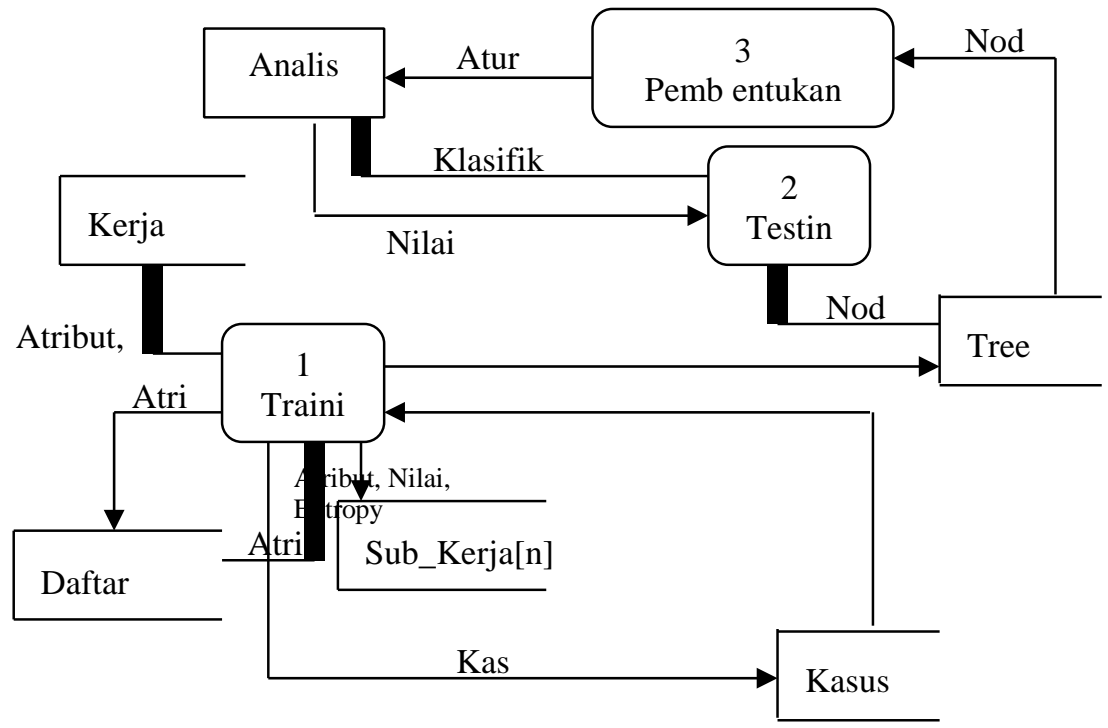

Gambar 3. Diagram Alir Data Level 1

Tabel 1. Nilai Ujian Tertulis

Tabel 2. Nilai

wawancara

\begin{tabular}{|c|c|}
\hline Nilai Ujian Tertulis & Klasifikasi \\
\hline $0-15$ & 1 \\
\hline $16-32$ & 2 \\
\hline $33-47$ & 3 \\
\hline $48-63$ & 4 \\
\hline $64-79$ & 5 \\
\hline$>80$ & 6 \\
\hline
\end{tabular}

\begin{tabular}{|c|c|}
\hline Nilai Ujian Praktek & Klasifikasi \\
\hline $0-15$ & 1 \\
\hline $16-32$ & 2 \\
\hline $33-47$ & 3 \\
\hline $48-63$ & 4 \\
\hline $64-79$ & 5 \\
\hline$>80$ & 6 \\
\hline
\end{tabular}

Praktek

Tabel 4.

\begin{tabular}{|c|c|}
\hline Wawancara & Klasifikasi \\
\hline Hadir & Ya \\
\hline Tidak Hadir & Tidak \\
\hline
\end{tabular}

Nilai IPK

\begin{tabular}{|c|c|}
\hline $\begin{array}{l}\text { Nilai Rata-rata } \\
\text { IPK }\end{array}$ & Klasifikasi \\
\hline $0,00-0,90$ & 1 \\
\hline $0,91-1,00$ & 2 \\
\hline $1,01-1,90$ & 3 \\
\hline $1,91-2,00$ & 4 \\
\hline $2,01-2,90$ & 5 \\
\hline$>2,91$ & 6 \\
\hline
\end{tabular}




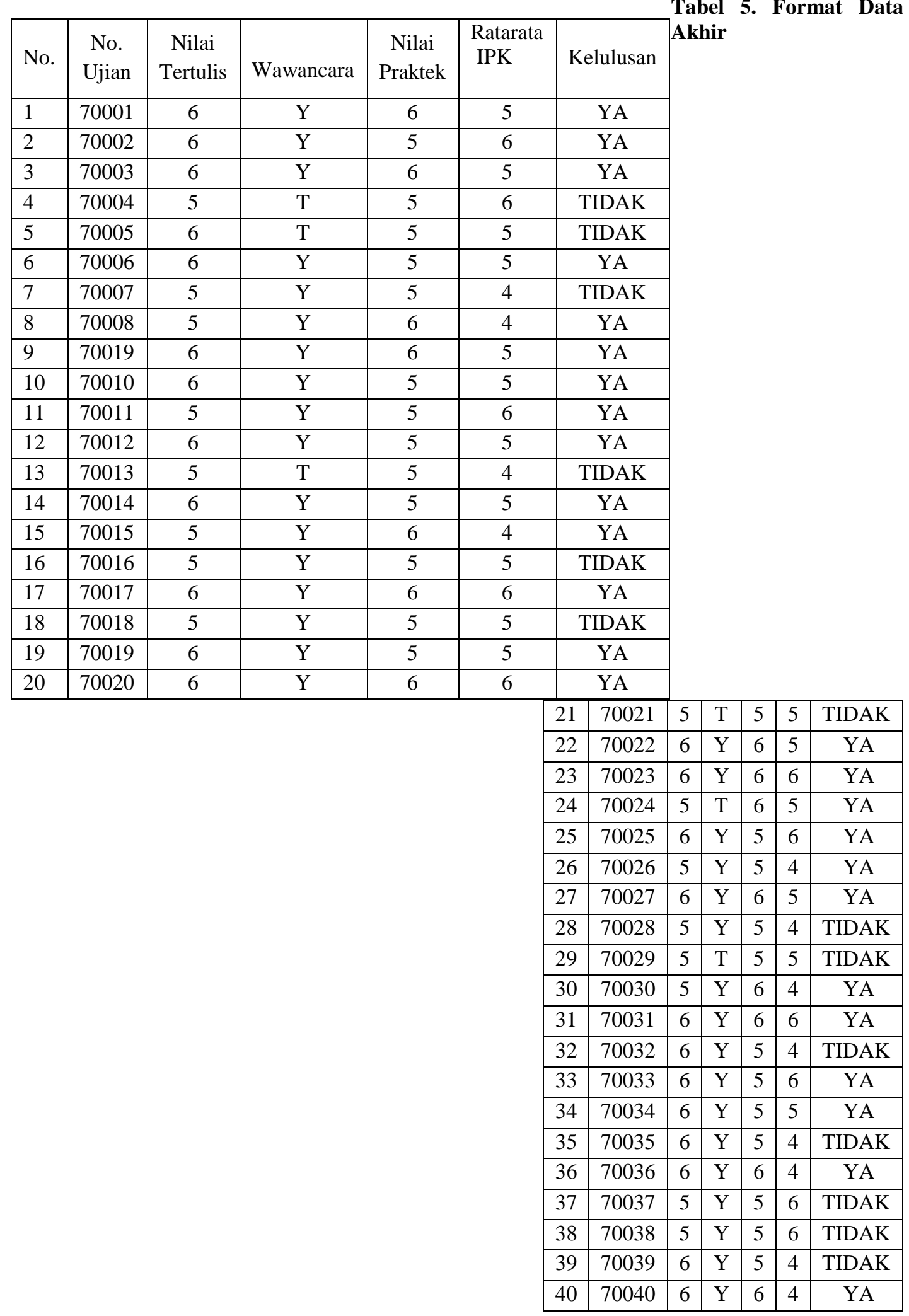




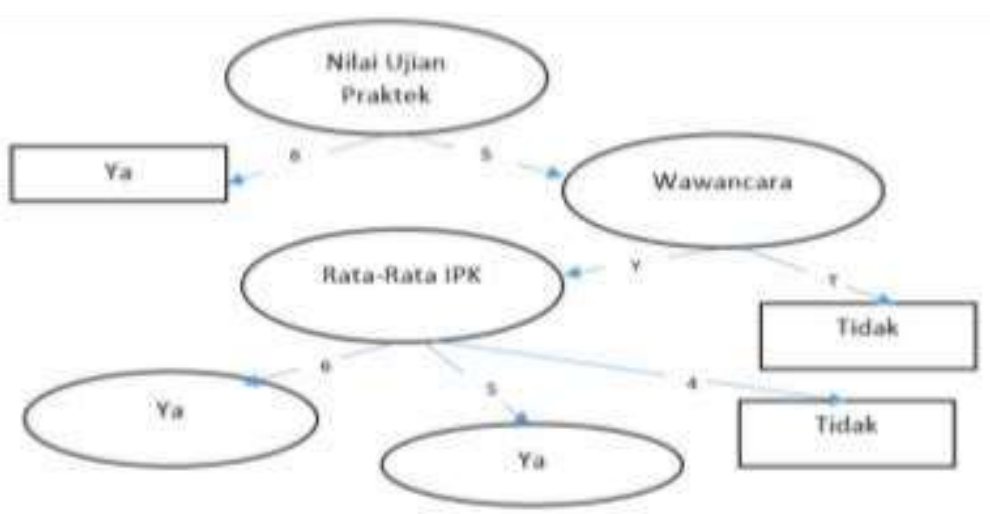

Gambar 4. Pohon Keputusan Hasil Perhitungan Node Akhir
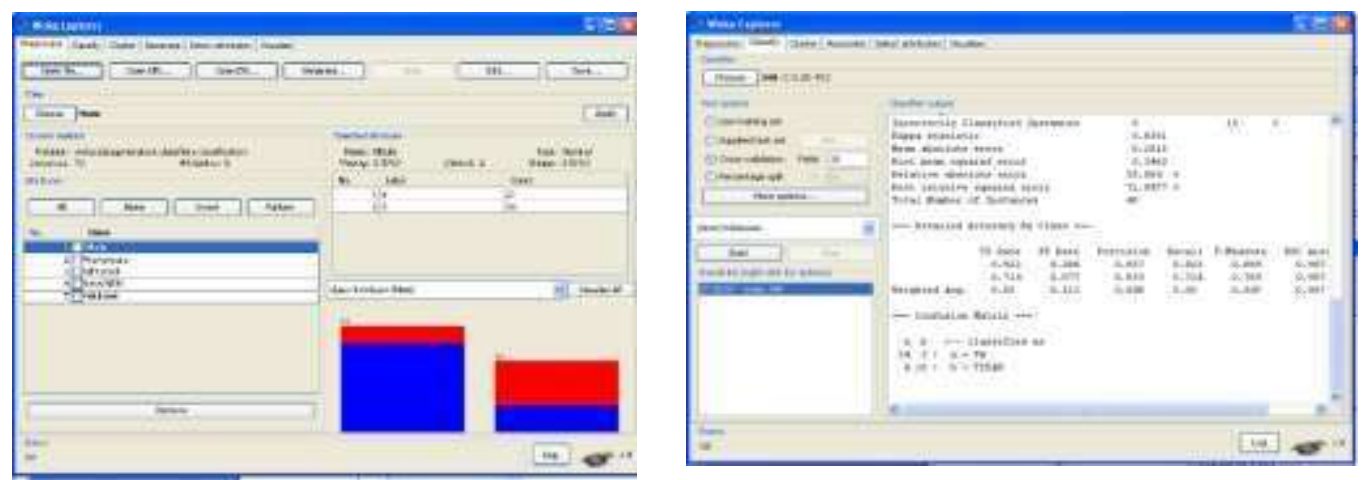

Gambar 5. WEKA Explorer dengan Visualisasi Data Gambar 6. Hasil Classifier

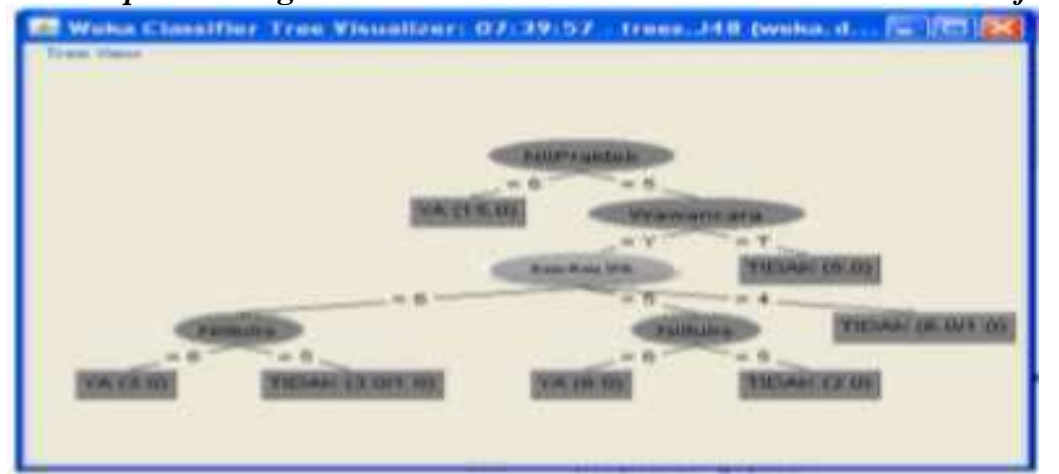

Gambar 7. Hasil Visualisasi Tree

\section{Kesimpulan}

Dari dua hasil pengujian yang telah dilakukan yaitu proses secara manual dan menggunakan software WEKA 3.6 dapat kita ambil sebuah kesimpulan bahwa hasil pengujian sangat baik karena rule yang dihasilkan hampir sama. Berdasarkan rule yang dihasilkan secara umum dapat dilihat bahwa calon Dosen baru yang mempunyai nilai yang bagus pada nilai ujian tertulis, nilai praktek, wawancara, dan rata-rata IPK akan lulus dalam seleksi penerimaan calon Dosen baru, begitu juga sebaliknya. Algoritma C 4.5 dianggap sebagai algoritma yang sangat membantu dalam melakukan klasifikasi data karena karakteristik data yang diklasifikasi dapat diperoleh dengan jelas, baik dalam bentuk struktur pohon keputusan maupun aturan if-then, sehingga memudahkan pengguna dalam melakukan penggalian informasi terhadap data yang bersangkutan. Tapi hasil pengujian ini belum dapat dikatakan valid karena pada penelitian ini hanya menggunakan salah satu teknik untuk memprediksi yaitu teori Decision Tree. Oleh sebab itu perlunya dilakukan penelitian lanjutan untuk membandingkan hasil prediksi dan menentukan teori mana yang menghasilkan prediksi yang baik.

\section{Daftar Pustaka}


[1] Agrawal R. and Srikant R. (1994). Fast Algorithm for Mining Association Rules. VLDB Conference.

[2] Andika Prajana. (2011). Jurnal Perbandingan Data Mining Perbandingan Manajemen Laba Terhadap Persistensi Laba pada Perusahaan Perbankan yang Go Publik di Bursa Efek Indonesia.

[3] Azhari dan Anshori. (2009). Jurnal Data Mining Pendekatan Aturan Asosiasi Untuk Analisa Pergerakan Saham.

[4] Dian Wirdasari dan Ahmad Calam. (2011). Jurnal Penerapan Data Mining Untuk Mengolah data Penempatan Buku Di Perpustakaan SMK TI Pab 7 Lubuk Pakam Dengan Metode Association Rule.

[5] Eko Wahyu Tyas. (2008). Jurnal Data Mining Penerapan Metode Association Rule Menggunakan Algoritma Apriori untuk Analisa pola Data Hasil Tangkapan Ikan.

[6] Eko Nur, Arif dan Narwati. (2011). Jurnal Analisa Profil data Mahasiswa Baru Terhadap Program Studi yang Dipilih di Perguruan Tinggi Swasta Dengan Teknik Data Mining.

[7] Fitrah Rumaisa. (2012). “Jurnal Penentuan Association Rule pada Pemilihan Program Studi Calon Mahasiswa Menggunakan Algoritma Apriori.

[8] Jiawei Han and Micheline Kamber. (2006). Data Mining: Concepts and Techniques, Morgan Kaufmann Publishers is an Imprint of Elsevier, San Francisco.

[9] Khafiizh Hastuti. ( 2012). Jurnal Analisa Komparasi Algoritma Klasifikasi Data Mining untuk Prediksi Mahasiswa Non Aktif.

[10] Kusrini1, Sri Hartati2, Retantyo Wardoyo3, Agus Harjoko4. (2009). Jurnal Perbandingan Metode Nearest Neighbor dan Algoritma C4.5 untuk Menganalisis Kemungkinan Pengunduran Diri Calon Mahasiswa di STMIK Amikom Yogyakarta.

[11] Moertini, Veronika dan Marsela Yulita. (2002). Analisis Keranjang Pasar Dengan Algoritma Hash-Based Pada Data Transaksi Penjualan Apotek. Jurusan Ilmu Komputer. Universitas Katolik Parahyangan. Bandung.

[12] Veronica Sri Moertini. (2007). Disertasi Pengembangan Skalabilitas Algoritma Klasifikasi C4.5 dengan Pendekatan Konsep Operator Relasi (Studi Kasus:Pra-Pengolahan dan Klasifikasi Citra Batik). 


\title{
TITLE OF THE PAPER, TIMES NEW ROMAN, 14 FONT SIZE, CENTER, BOLD, 100 CAPITAL LETTERSOR 2 LINES
}

\author{
First Autor ${ }^{1}$, Second Author ${ }^{2}$, Third Author ${ }^{3}$ \\ Institution/affiliation addres, telp/fax of \\ institution/affiliation e-mail: \\ xxxx@xxxx.xxx
}

\begin{abstract}
A well-prepared abstract enables the reader to identify the basic content of a document quickly and accurately, to determine its relevance to their interests, and thus to decide whether to read the document in its entirety. The Abstract should be informative and completely self-explanatory, provide a clear statement of the problem, the proposed approach or solution, and point out major findings and conclusions. The Abstract should be 100 to 150 words in length. The abstract should be written in the past tense. Standard nomenclature should be used and abbreviations should be avoided. No literature should be cited. The keyword list provides the opportunity to add keywords, used by the indexing and abstracting services, in addition to those already present in the title. Judicious use of keywords may increase the ease with which interested parties can locate our article.
\end{abstract}

Keywords: maximum 5 keywords from paper

\section{Introduction}

Paper size $210 \mathrm{~mm} \times 297 \mathrm{~mm}$ of A4 paper. Please save to MS Word templates directory. Use 10 point Times New Roman font. Single line spacing is mandatory. Try to avoid Underline or Bold within texts. Throughout the paper including text inside figures and tables must follow 10 Font size or larger.

Top margin is $30 \mathrm{~mm}$ while the left, right, and bottom margins are $25 \mathrm{~mm}$. Headings should be all left justified and numbering. Leave one line between headings and the first paragraph and no space before succeeding paragraphs. Indent the first line of the paragraph by $5 \mathrm{~mm}$. All text should be left and right justified. Footnotes and underlines are not allowed.

\section{Research Method}

Explaining research chronological, including research design, research procedure (in the form of algorithms, Pseudocode or other), how to test and data acquisition [1], [3]. The description of the course of research should be supported references, so the explanation can be accepted scientifically [2], [4]. Tables and Figures are presented center, as shown below and cited in the manuscript.

Table 1. Basic Data Promethee

Figure 1.

\begin{tabular}{|c|c|c|c|c|c|}
\hline & $f_{1}()$. & $f_{2}()$. & $\ldots$ & $f_{j}()$. & $f_{k}()$. \\
\hline$a_{1}$ & $f_{1}\left(a_{1}\right)$ & $f_{2}\left(a_{1}\right)$ & $\ldots$ & $f_{j}\left(a_{1}\right)$ & $f_{k}\left(a_{1}\right)$ \\
\hline$a_{2}$ & $f_{1}\left(a_{2}\right)$ & $f_{2}\left(a_{2}\right)$ & $\ldots$ & $f_{j}\left(a_{2}\right)$ & $f_{k}\left(a_{2}\right)$ \\
\hline$\ldots$ & $\ldots$ & $\ldots$ & $\ldots$ & $\ldots$ & $\ldots$ \\
\hline$a_{i}$ & $f_{1}\left(a_{i}\right)$ & $f_{2}\left(a_{i}\right)$ & $\ldots$ & $f_{j}\left(a_{i}\right)$ & $f_{k}\left(a_{i}\right)$ \\
\hline$\ldots$ & $\ldots$ & $\ldots$ & $\ldots$ & $\ldots$ & $\ldots$ \\
\hline$a_{n}$ & $f_{1}\left(a_{n}\right)$ & $f_{2}\left(a_{n}\right)$ & $\ldots$ & $f_{j}\left(a_{n}\right)$ & $f_{k}\left(a_{n}\right)$ \\
\hline
\end{tabular}

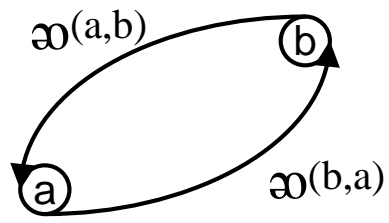

Node

\section{Results and Analysis}

In this section, it is explained the results of research and at the same time is given the comprehensive discussion. Results can be presented in figures, graphs, tables and others that make the reader understand easily [2], [5]. The discussion can be made in several sub-chapters.

\section{Conclusion}

Provide a statement that what is expected, as stated in the "Introduction" chapter can ultimately result in "Results and Discussion" chapter, so there is compatibility. Moreover, it can also be added the prospect of the development of research results and application prospects of further studies into the next (based on result and discussion). 


\section{References}

References are written in Vancouver style. Please use a consistent format for references - see examples below:

[1] Casadei D, Serra G, Tani K. Implementation of a Direct Control Algorithm for Induction Motors Based on Discrete Space Vector Modulation. IEEE Transactions on Power Electronics. 2007; 15(4): 769-777. (in this case Vol.15, Issues 4, and page 769-777)

[2] Calero C, Piatiini M, Pascual C, Serrano MA. Towards Data Warehouse Quality Metrics. Proceedings of the 3rd Intl. Workshop on Design and Management of Data Warehouses (DMDW). Interlaken. 2009; 39: 2-11. (in this case, city: Interlaken, year: 2009, Vol.39, page: 211)

[3] Yamin L, Wanming C. Implementation of Single Precision Floating Point Square Root on FPGAs. IEEE Symposium on FPGA for Custom Computing Machines. Napa. 2008: 226-232.

[4] Mohan N, Undeland TM, Robbins WP. Power Electronics. New York: John Wiley \& Sons. 2005 : 11-13.

[5] Ward J, Peppard J. Strategic planning for Information Systems. Fourth Edition. West Susse: John Willey \& Sons Ltd. 2007: 102-104.

[6] Mohan N, Undeland TM, Robbins WP. Power Electronics. New York: John Wiley \& Sons. 2005.

[7] Ward J, Peppard J. Strategic planning for Information Systems. Fourth Edition. West Susse: John Willey \& Sons Ltd. 2007.

[8] Rusdi M. A Novel Fuzzy ARMA Model for Rain Prediction in Surabaya. PhD Thesis. Surabaya: Postgraduate ITS; 2009.

[9] IEEE Standards Association. 1076.3-2009. IEEE Standard VHDL Synthesis Packages. New York: IEEE Press; 2009. 
Template 
Lembaga Penelitian dan Pengabdian Masyarakat STMIK Dharmasraya 